\title{
ROLE OF SHEAR WALLS IN HIGH RISE BUILDINGS
}

Hamdy H. A. Abd-el-Rahim ${ }^{(1)}$ and

Ahmed Abd El-Raheem Farghaly ${ }^{(2)}$

(1) Associate Professor, Civil engineering department, Assiut university

(2) Lecturer, Faculty of Industrial Education, Sohag University

(Received January 10, 2010 Accepted January 25, 2010).

The slender high rise buildings are wide spreading in Egypt and no probabilistic assessment procedures have been proposed or developed for seismic risk evaluation of these special buildings. So, the objective of this study is to numerically investigate the role of both edge shear walls and raft foundation projection out of the boundary of building in the seismic resistant of such structures. Several three-dimension models were developed including the subgrade modulus as a variable and the multipurpose commercial finite element program SAP2000 [6] was utilized for all runs in the current study. The loading is considered using acceleration time history with a peak ground acceleration of $0.25 \mathrm{~g}$ provided in the new Egyptian code (ECOL2008)[2] for seismic loads on structures and building works. The results conclude that the slender high rise buildings provided with edge shear walls and raft projection insure significant improvement in the induced base shear and internal forces in the raft foundation. On the contrary, the study shows the large values of base shear in the corner columns under seismic loads in a projected raft foundation building. The results give a wide vision that can be used as an aid to the engineer for dealing with such slender high buildings.

KEYWORDS: shear wall - slender high rise building - raft foundation projection - base shear - SAP2000- Time history analysis.

\section{INTRODUCTION}

Elnashai and Kuchma (2007) [3] conclude that for the worldwide rapid growth of highrise buildings, no probabilistic assessment procedures have been proposed or developed for seismic risk evaluation of this special building group. Reinforced concrete (RC) buildings often have vertical plate-like $\mathrm{RC}$ walls called Shear Walls in addition to slabs, beams and columns. These walls generally start at foundation level and are continuous throughout the building height. Their thickness can be as low as $150 \mathrm{~mm}$, or as high as $400 \mathrm{~mm}$ in high rise buildings. Shear walls are usually provided along both length and width of buildings. Shear walls are like vertically-oriented wide beams that carry earthquake loads downwards to the foundation.

A simplified analytical model is proposed for modeling the nonlinear response of flexural-yielding reinforced concrete walls using standard structural analysis software. The program SAP2000 is used to implement the proposed model for evaluating structural response by means of nonlinear response history analysis. The 
model is useful for performing practical nonlinear static or nonlinear dynamic procedures.

The walls are modeled using a fine mesh of linear-response shell elements coupled with uniaxial line elements. The use of line elements allows one to invoke the typical nonlinear response parameters available for such elements.

In high-rise structures, shear walls are widely used to resist earthquake forces. Such forces produce large displacement, vibration and big moments in building which lead to an unsafe building and causing discomfort to the occupants. The reinforced concrete shear walls are quite stiff in their own plane. Therefore, shear wall frame buildings of varying number of stories are considered in the present analysis.

The time history analysis of the multi-story shear wall frame buildings is carried out using SAP2000 software. The time history function obtained from elCentro for Egypt are provided in SAP2000 for performing the analysis.

Elnashai and KUCHMA (2007) [3] illustrate that the shear walls are acting as cantilever girders which support beams represented by the floor diaphragms. However, unlike a normal cantilever supporting gravity forces, the shear wall must resist dynamic forces that are reversing their direction, for as long as the strong motion continues depending on the earthquake characteristics. The size and location of shear walls is extremely critical. Plans can be conceived of as collections of resistant elements with varying orientations to resist translational forces, and placed at varying distances from the centre of rigidity to resist torsional forces.

Properly designed and detailed buildings with shear walls have shown very good performance in past earthquakes. The overwhelming success of buildings with shear walls in resisting strong earthquakes is summarized in the quote: "We cannot afford to build concrete buildings meant to resist severe earthquakes without shear walls." Shear walls are easy to construct, because reinforcement detailing of walls is relatively straight-forward and therefore easily implemented at site. Shear walls are efficient, both in terms of construction cost and effectiveness in minimizing earthquake damage in structural and nonstructural elements (like glass windows and building contents). Most RC buildings with shear walls also have columns; these columns primarily carry gravity loads (i.e., those due to self-weight and contents of building). Shear walls provide large strength and stiffness to buildings in the direction of their orientation, which significantly reduces lateral sway of the building and thereby reduces damage to structure and its contents.

Since shear walls carry large horizontal earthquake forces, the overturning effects on them are large. Thus, design of their foundations requires special attention. Shear walls should be provided along preferably both length and width. However, if they are provided only along one direction, a proper grid of beams and columns in the vertical plane (called a moment-resistant frame) must be provided along the other direction to resist strong earthquake effects.

Shear walls in buildings must be symmetrically located in plan to reduce illeffects of twist in buildings. They could be placed symmetrically along one or both directions in plan. Shear walls are more effective when located along exterior perimeter of the building -such a layout increases resistance of the building to twisting.

Where shear walls are connected by a rigid diaphragm so that they must deflect equally under horizontal load, the proportion of total horizontal load at any story or level carried by a perpendicular shear wall is based on its relative rigidity or 
stiffness. The rigidity of a shear wall is inversely proportional to its deflection under unit horizontal load. The total deflection of the shear wall can be determined from the sum of the shear and moment deflections.

The use of shear walls in the earthquake-resistant structural system of reinforced concrete buildings is not often in earthquake-prone countries. Nevertheless, the lessons learned from the seismic behavior of Chilean buildings during the March 3, 1985 earthquake, show that satisfactory seismic behavior may be achieved during severe earthquake events, when the total amount of wall cross sections is large enough, i.e., 0.02 to 0.03 times the floor plan area in each direction of seismic resistance for buildings up to 25-story high. In this event, both flexural yielding of boundary reinforcement and shear moments in walls were kept at a moderate level, nonstructural damage was adequately controlled due to the significant lateral stiffness of the structural system, and collapse of this type of buildings was practically prevented.

The horizontal interaction moments between the soil and the foundation are arguably more problematic than the vertical moments, as comparatively little is known about allowable seismic passive pressures and the effect of seismic active pressure in different foundation situations. Indeed it is customary to assume even more arbitrary distributions for horizontal moment between foundations and soil than for vertical moment. The main problems of foundation design as presently understood occur in transferring the base shear of the structure to the ground, and in maintaining structural integrity of the foundation during differential soil deformations.

According to The Council of Tall Buildings and Urban Habitat, the description of 'Tall building', equivalent to 'High-rise building' used herein, is: "A building whose height creates different conditions in the design, construction, and use than those that exist in common buildings of a certain region and period. A traditional height cutoff between high-rise and low-rise buildings is 35 meters or 12 floors. This distinction is used as 12-floors are generally considered to be the minimum height needed to achieve the physical presence to earn the recognition as a "high-rise". The twelve-floor limit is also seen as a compromise between ambition and manageability for use in classification of buildings in a worldwide database.

\subsection{Structural Types}

The significant innovation in high-rises was proposed by Khan and Rankine (1980)[5], who proposed the idea of using a hollow thin-walled tube with punched holes to form the exterior of buildings. By reducing the spacing of exterior columns, the entire system of beams and columns lying on the external perimeter of a building can be made to act as a perforated or framed tube.

The analysis methods Ali (2001)[1] for RC high-rise buildings have special requirements different from low-to-middle rise buildings, especially for the typical structural system that consists of slender members in frames and more RC stocky structural walls. The complexities of concrete properties, wall-frame interaction and three-dimensional effects need to be accounted for in structural modeling

\subsection{Description of model}

The model is consists of frame elements as beam and column the column dimension is $65 \times 65 \mathrm{~cm}$ and the beam section is $25 \times 75 \mathrm{~cm}$ and the shell element for the 
description of slab, walls, and foundation the slab mesh thickness is $14 \mathrm{~cm}$ and shear wall thickness $20 \mathrm{~cm}$ constant thickness all over the height of the building foundation is a raft foundation with thickness $130 \mathrm{~cm}$ modeled as shell elements constant thickness

The model is a building of $12^{\text {th }}$ stories with height each story $3.00 \mathrm{~m}$ the length of the building as shown in figure $20 \mathrm{~m}$ and width $10 \mathrm{~m}$ see figure 1 .

No matter what type and size of RC structure is under investigation the finite element method (FEM) is the most accurate and reliable analytical technique for assessing the demands on structure components in both 2D and 3D domains.

Frame members primarily serve to carry the majority of gravity loads in a building, but also serve as part of lateral resisting systems. Bernoulli-Euler beam theory and Timoshenko beam theory (Hjelmstad (2005))[4] if considering shear effects for deep beam, are widely used and have been implemented into most computer-based frame analysis packages.

Floor system in high-rise buildings functions not only provides gravity load resistance, but also provides constraints between frames, walls, and core and outrigger systems, with great contribution to spatial components interactions.

Time history analysis is carried out considering the factor of acceleration $0.25 \mathrm{~g}$ as Egypt zone and nonlinear analysis with 4000 step and $40 \mathrm{sec}$. The time history corresponding to 5\% damping is considered which is reasonable for concrete structure.

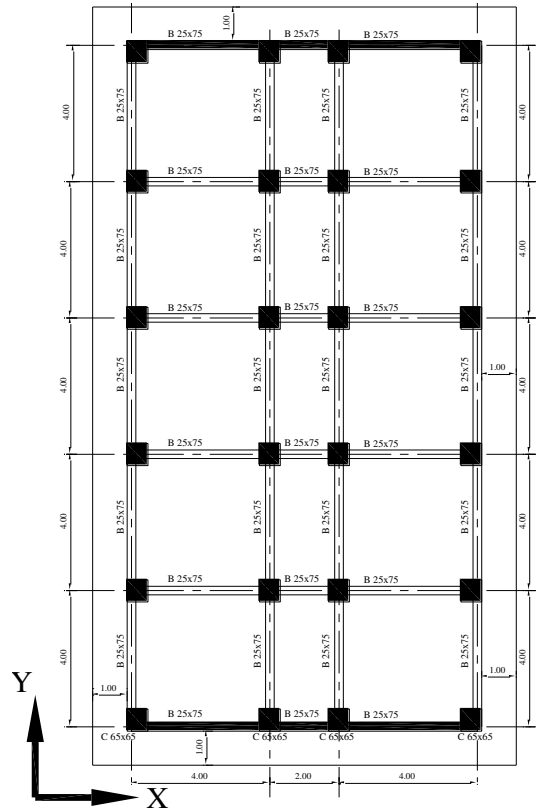

a) The building plan with the two sides

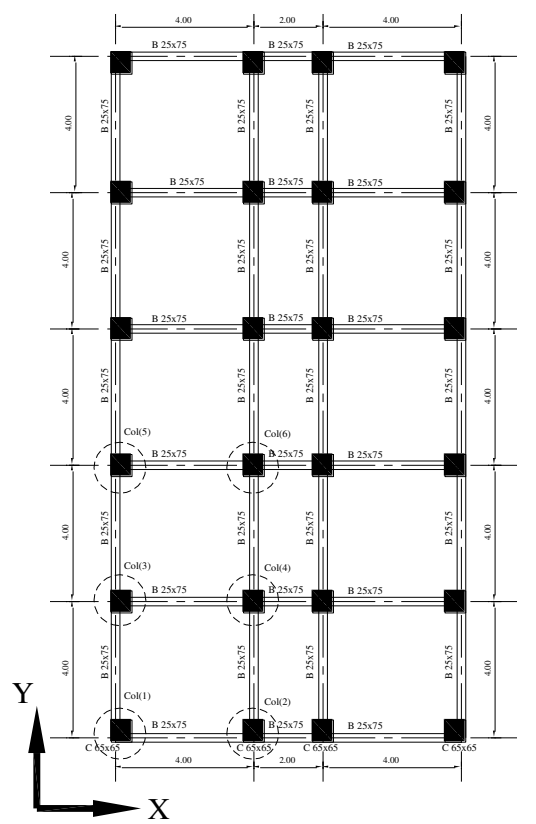

b) The original building shear walls and $1 \mathrm{~m}$ projection

Figure 1: The plans of the different investigated building

\section{CASES OF STUDY}

To study the effect of the earthquake on the selected model (A $12^{\text {th }}$ stories building) and give the best performance of the building to resist the earthquake force cases of 
study selected that can be give more efficiency of the building under the earthquake lateral force this cases are:

1. Study of the building straining action under lateral earthquake force without any addition element to the original building without any projection out of the boundary of the building

2. The building with two shear walls in both sides of the building all over the height of the building without projection of the foundation after the border of the column

3. The building with two shear walls in both sides of the building all over the height of the building with a $1 \mathrm{~m}$ projection from the boundary of the raft foundation

4. The building without shear walls but with a $1 \mathrm{~m}$ projection out of the boundary of the building.

The study include the effect of the bearing capacity of the soil under the raft foundation modeling these different bearing capacity of the soil as a stiffness in Zdirection $\mathrm{K}=1500 \mathrm{t} / \mathrm{m}^{\prime}, \mathrm{K}=2000 \mathrm{t} / \mathrm{m}^{\prime}$, and $\mathrm{K}=2500 \mathrm{t} / \mathrm{m}^{\prime}$. The values of the differences stiffness represent the values of differences types of soils that may be used by Egyptian designer.

\subsection{Results and discussion}

This study aimed to find the real effect of the shear wall in frame slender high rise building.

The shear wall although affect the moment distribution on the raft foundation under the super structure. The projection of the raft foundation will be used to show how it will affect the moment distribution on the raft foundation under the super structure.

The base shear of the column will be found in four cases the may be happened in the reality the first case no use of the projection and no use of shear wall and this case will be the reference case that will be camper to the other cases. The second case used is construction two side shear wall in the super structure and no projection in raft foundation. The third case is the ideal case by using two side shear wall and a $1 \mathrm{~m}$ projection around the raft foundation. The fourth case is using only the $1 \mathrm{~m}$ projection around the raft foundation and without shear walls.

Figure 2 (a) shows the effect of the shear walls and projection stats and with stiffness $K=1500 t / m^{\prime}$ on the base shear of the critical column in the building. It can be recognized that the base shear in column (1) in case two shear wall without projection decrease by $63 \%$, the base shear increase by 1.35 times in case of two shear walls and $1 \mathrm{~m}$ projection, and the base shear increase by 1.74 times in case of no shear walls and $1 \mathrm{~m}$ projection with respect to the case without shear walls and projection.

The column (2) in case of two shear wall without projection decrease by $80 \%$, the base shear decrease by $84 \%$ in case of two shear walls and $1 \mathrm{~m}$ projection, and the base shear increase by 1.37 times in case of no shear walls and $1 \mathrm{~m}$ projection with respect to the case without shear walls and projection.

The column (3) in case of two shear wall without projection decrease by $40 \%$, the base shear decrease by $33 \%$ in case of two shear walls and $1 \mathrm{~m}$ projection, and the base shear increase by 1.46 times in case of no shear walls and $1 \mathrm{~m}$ projection with respect to the case without shear walls and projection. 
The column (4) in case of two shear wall without projection decrease by $40 \%$, the base shear decrease by $48 \%$ in case of two shear walls and $1 \mathrm{~m}$ projection, and the base shear increase by 1.22 times in case of no shear walls and $1 \mathrm{~m}$ projection with respect to the case without shear walls and projection.

The column (5) in case of two shear wall without projection decrease by $20 \%$, the base shear decrease by $13 \%$ in case of two shear walls and $1 \mathrm{~m}$ projection, and the base shear increase by 1.4 times in case of no shear walls and $1 \mathrm{~m}$ projection with respect to the case without shear walls and projection.

The column (6) in case of two shear wall without projection decrease by $20 \%$, the base shear decrease by $28 \%$ in case of two shear walls and $1 \mathrm{~m}$ projection, and the base shear increase by 1.2 times in case of no shear walls and $1 \mathrm{~m}$ projection these with respect to the case without shear walls and projection.

Figure 2 (b) shows the effect of the shear walls and projection stats and with stiffness $\mathrm{K}=2000 \mathrm{t} / \mathrm{m}^{`}$ on the base shear of the critical column in the building. It can be recognized that the base shear in column (1) in case two shear wall without projection decrease by $56 \%$, the base shear increase by 1.03 times in case of two shear walls and $1 \mathrm{~m}$ projection, and the base shear increase by 1.31 times in case of no shear walls and $1 \mathrm{~m}$ projection with respect to the case without shear walls and projection.

The column (2) in case of two shear wall without projection decrease by $78 \%$, the base shear decrease by $87 \%$ in case of two shear walls and $1 \mathrm{~m}$ projection, and the base shear increase by 1.02 times in case of no shear walls and $1 \mathrm{~m}$ projection with respect to the case without shear walls and projection.

The column (3) in case of two shear wall without projection decrease by $30 \%$, the base shear decrease by $50 \%$ in case of two shear walls and $1 \mathrm{~m}$ projection, and the base shear increase by 1.08 times in case of no shear walls and $1 \mathrm{~m}$ projection with respect to the case without shear walls and projection.

The column (4) in case of two shear wall without projection decrease by $30 \%$, the base shear decrease by $63 \%$ in case of two shear walls and $1 \mathrm{~m}$ projection, and the base shear decrease by $10 \%$ in case of no shear walls and $1 \mathrm{~m}$ projection with respect to the case without shear walls and projection.

The column (5) in case of two shear wall without projection decrease by $8 \%$, the base shear decrease by $37 \%$ in case of two shear walls and $1 \mathrm{~m}$ projection, and the base shear increase by 1.04 times in case of no shear walls and $1 \mathrm{~m}$ projection with respect to the case without shear walls and projection.

The column (6) in case of two shear wall without projection decrease by $8 \%$, the base shear decrease by $48 \%$ in case of two shear walls and $1 \mathrm{~m}$ projection, and the base shear decrease by $13 \%$ in case of no shear walls and $1 \mathrm{~m}$ projection these with respect to the case without shear walls and projection.

Figure 2 (c) shows the effect of the shear walls and projection stats and with stiffness $\mathrm{K}=2500 \mathrm{t} / \mathrm{m}$ ' on the base shear of the critical column in the building. It can be recognized that the base shear in column (1) in case two shear wall without projection decrease by $72 \%$, the base shear increase by 1.06 times in case of two shear walls and $1 \mathrm{~m}$ projection, and the base shear increase by 1.19 times in case of no shear walls and $1 \mathrm{~m}$ projection with respect to the case without shear walls and projection.

The column (2) in case of two shear wall without projection decrease by $86 \%$, the base shear decrease by $85 \%$ in case of two shear walls and $1 \mathrm{~m}$ projection, and the 
base shear decrease by $9 \%$ in case of no shear walls and $1 \mathrm{~m}$ projection with respect to the case without shear walls and projection.

The column (3) in case of two shear wall without projection decrease by $58 \%$, the base shear decrease by $52 \%$ in case of two shear walls and $1 \mathrm{~m}$ projection, and the base shear decrease by $3 \%$ in case of no shear walls and $1 \mathrm{~m}$ projection with respect to the case without shear walls and projection.

The column (4) in case of two shear wall without projection decrease by $48 \%$, the base shear decrease by $63 \%$ in case of two shear walls and $1 \mathrm{~m}$ projection, and the base shear decrease by $19 \%$ in case of no shear walls and $1 \mathrm{~m}$ projection with respect to the case without shear walls and projection.

The column (5) in case of two shear wall without projection decrease by $44 \%$, the base shear decrease by $38 \%$ in case of two shear walls and $1 \mathrm{~m}$ projection, and the base shear decrease by $6 \%$ in case of no shear walls and $1 \mathrm{~m}$ projection with respect to the case without shear walls and projection.

The column (6) in case of two shear wall without projection decrease by $44 \%$, the base shear decrease by $49 \%$ in case of two shear walls and $1 \mathrm{~m}$ projection, and the base shear decrease by $21 \%$ in case of no shear walls and $1 \mathrm{~m}$ projection these with respect to the case without shear walls and projection.

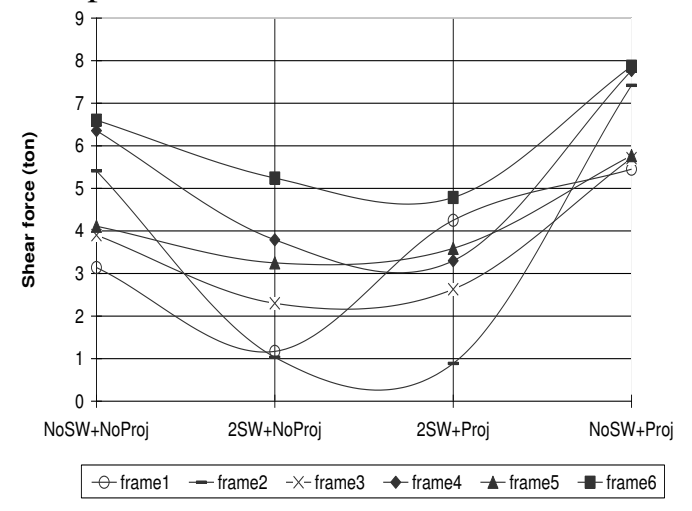

a) The base shear effect on the columns $1,2,3,4,5$, and 6 in case of stiffness $\mathrm{K}=1500 \mathrm{t} / \mathrm{m}^{\text {` }}$

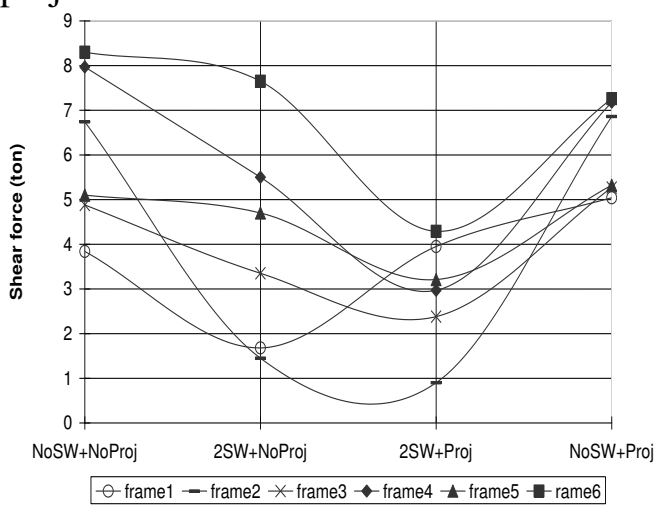

b) The base shear effect on the columns 1, 2, 3, 4, 5, and 6 in case of stiffness $\mathrm{K}=2000 \mathrm{t} / \mathrm{m}$

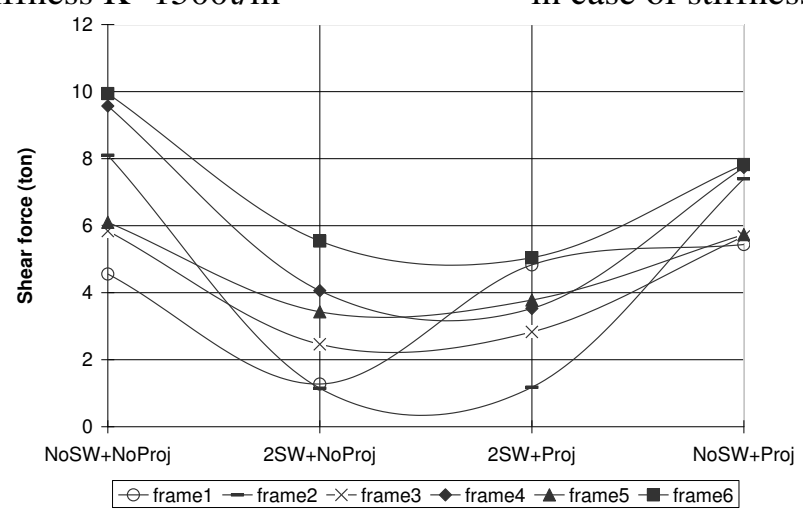

c) The base shear effect on the

columns $1,2,3,4,5$, and 6 in case of stiffness $\mathrm{K}=2500 \mathrm{t} / \mathrm{m}$ '

Figure 2: Effect of shear wall and projection on base shear of the building 
To study the effect of shear walls and projection on the raft foundation four cases will be study and then the moment in X-direction (M11) and moment in Ydirection (M22) will be study (see figure 3)

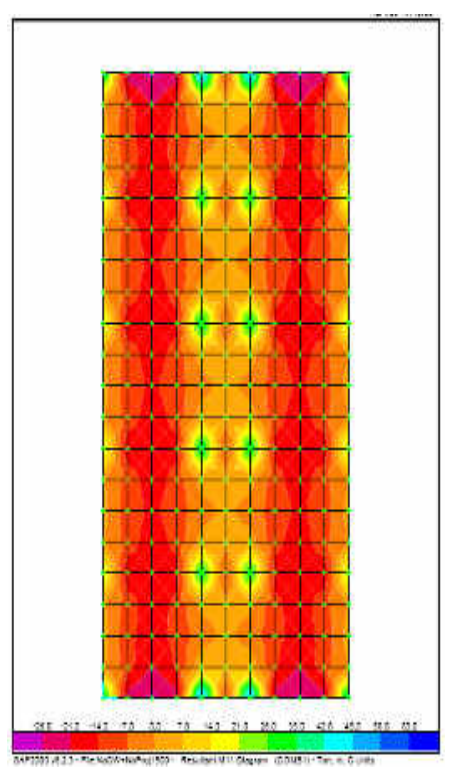

M11 (K1500t

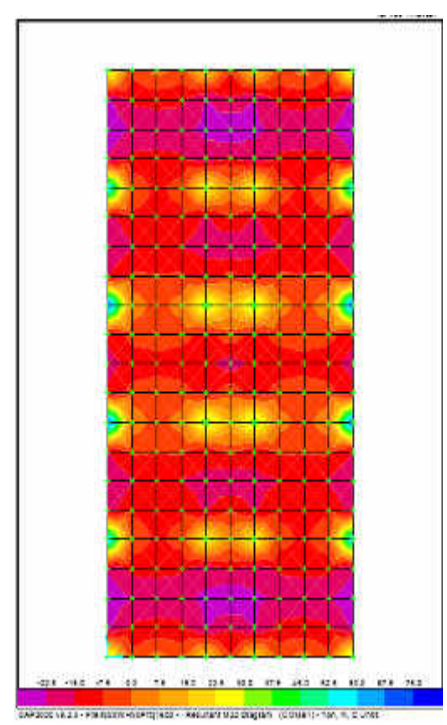

$\operatorname{M} 22\left(\mathrm{~K} 1500 \mathrm{t} / \mathrm{m}^{\prime}\right)$

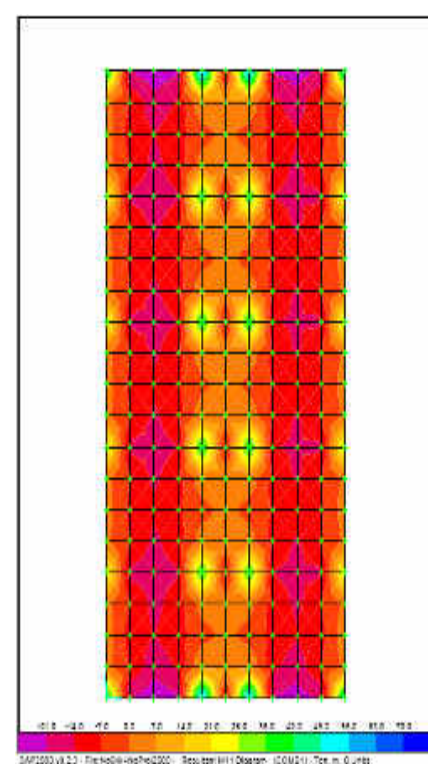

M11 (K2000t/m`)

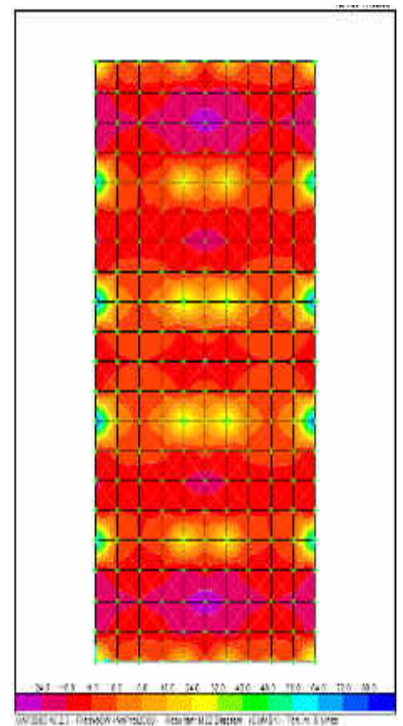

M22 (K2000t/m`)

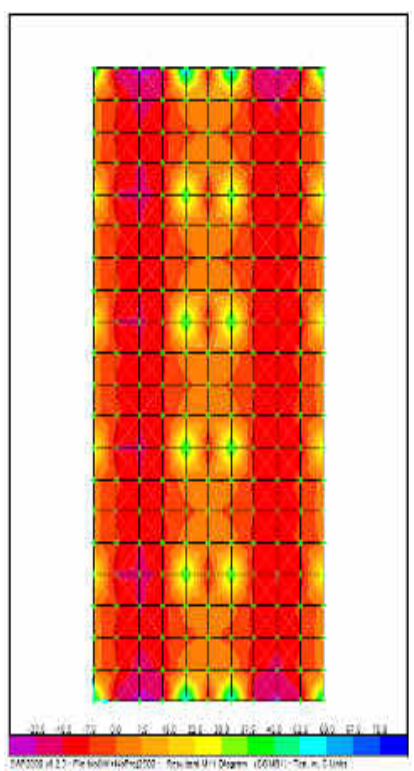

M11 (2500t/m`)

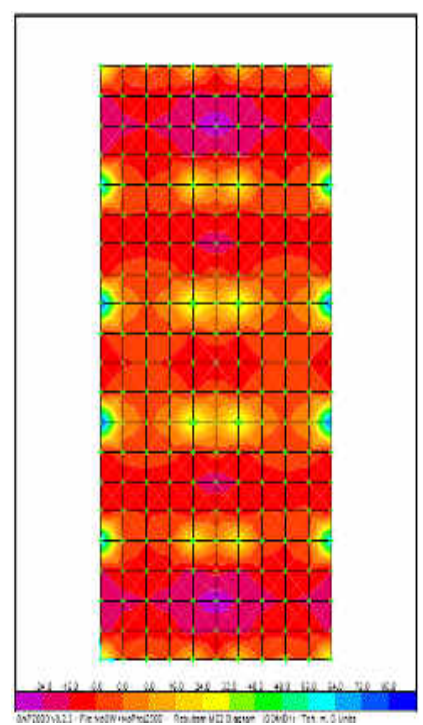

M22 (2500t/m`)

(I) Moment distribution on raft foundation without shear wall and projection 


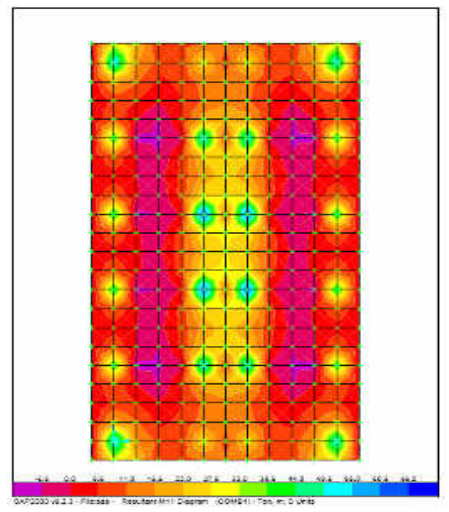

M11 (K1500t/m`)

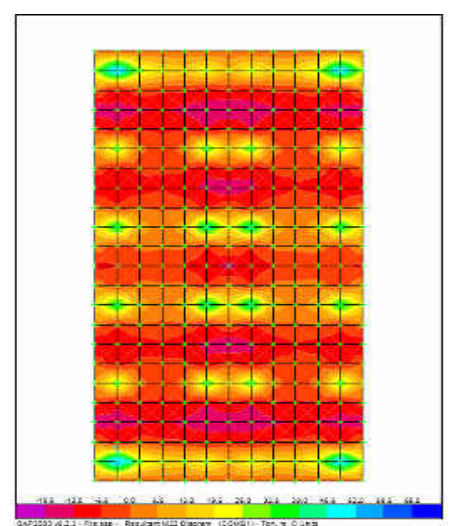

M22 (K1500 t/m`)

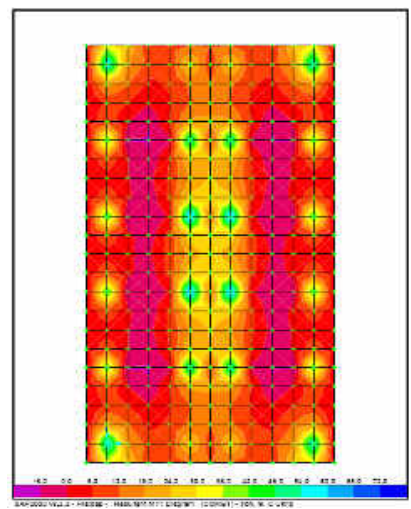

M11 (K2000t/m`)

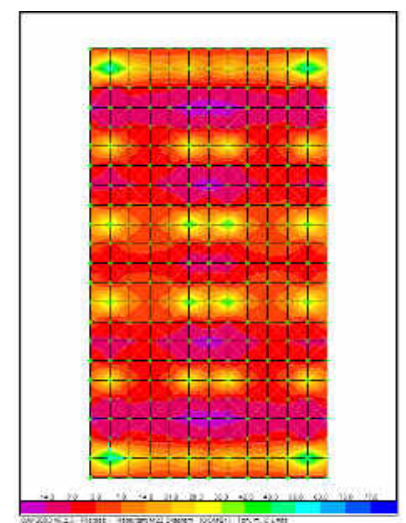

M22 (K2000t/m`)

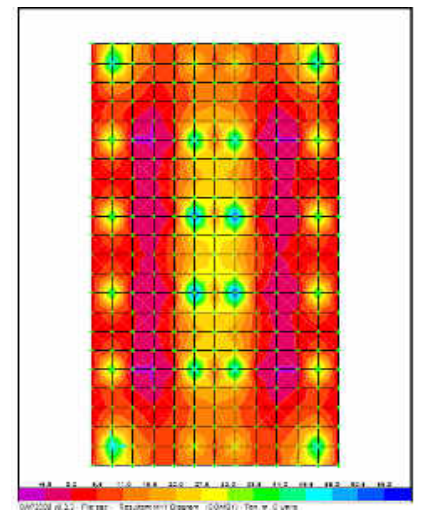

M11 (K2500t/m`)

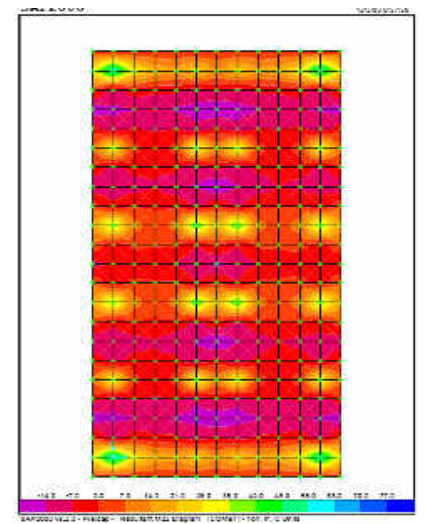

M22 (K2500t/m')

(II) Moment distribution on raft foundation with two shear walls and projection

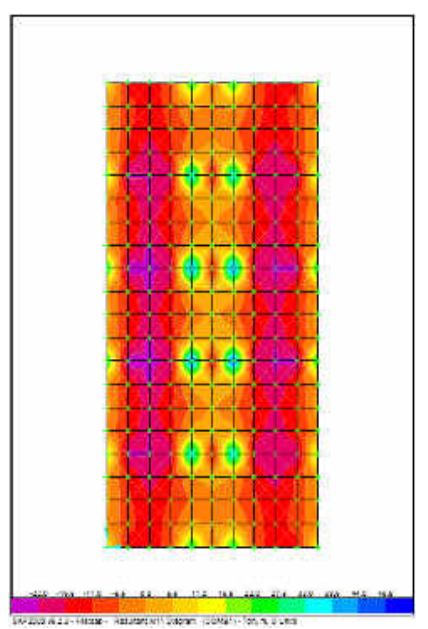

M11 (K1500t/m`)

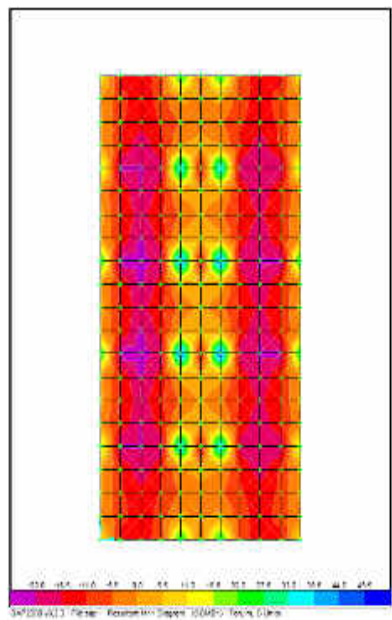

M11 (K2000t/m`)

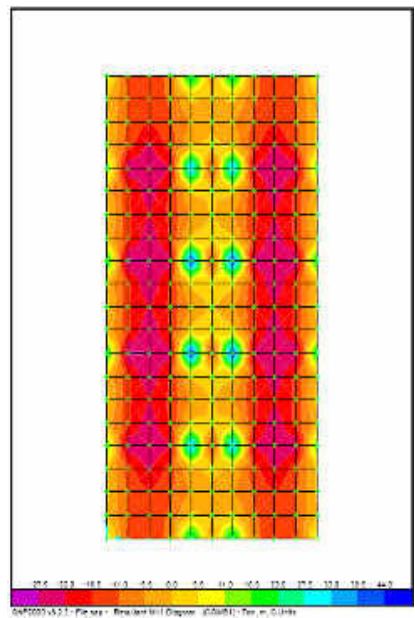

M11 (K2500t/m`) 


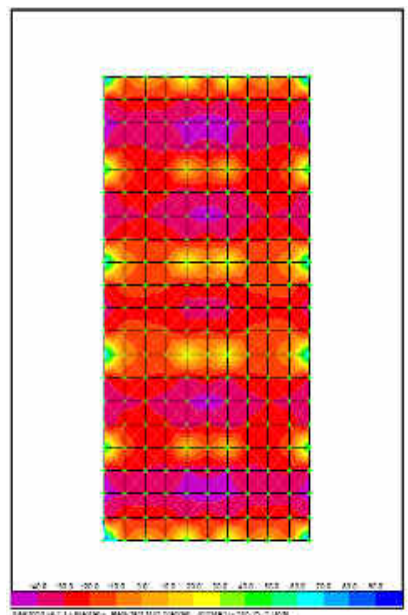

$\operatorname{M} 22\left(\mathrm{~K} 1500 \mathrm{t} / \mathrm{m}^{`}\right)$

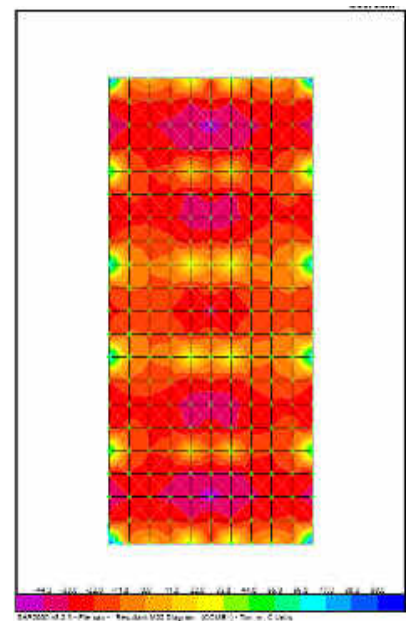

M22 (K2000t/m`)

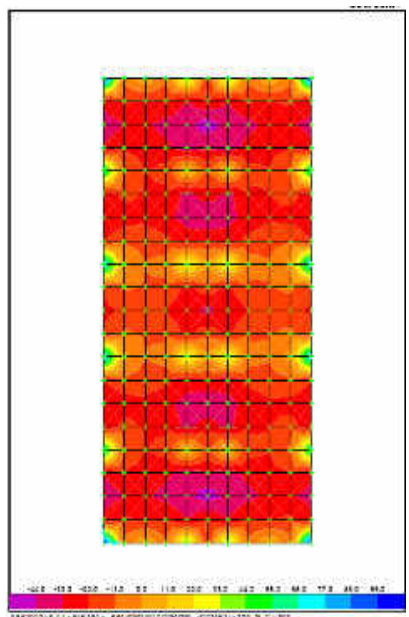

$\operatorname{M} 22\left(2500 t / \mathrm{m}^{`}\right)$

(III) Moment distribution on raft foundation with shear walls and no projection

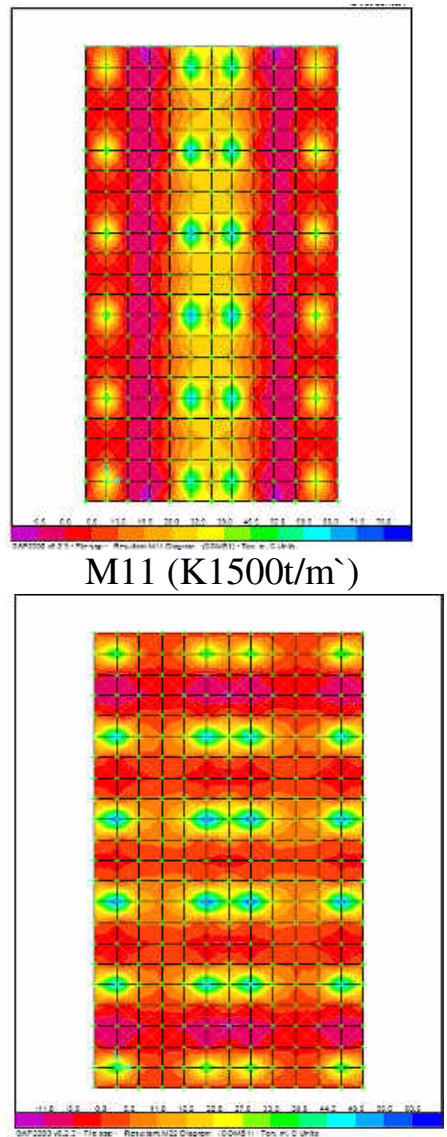

M22 (K1500t/m)
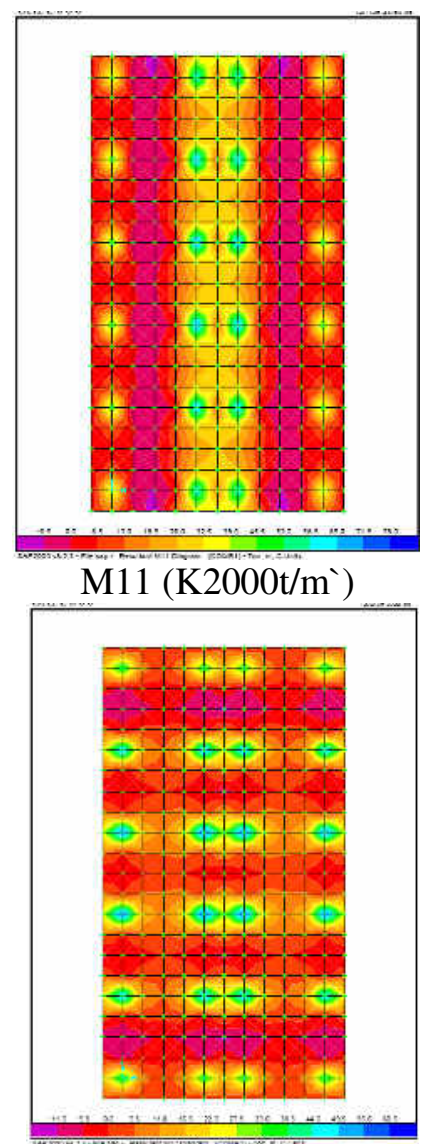

M22 (K2000t/m')

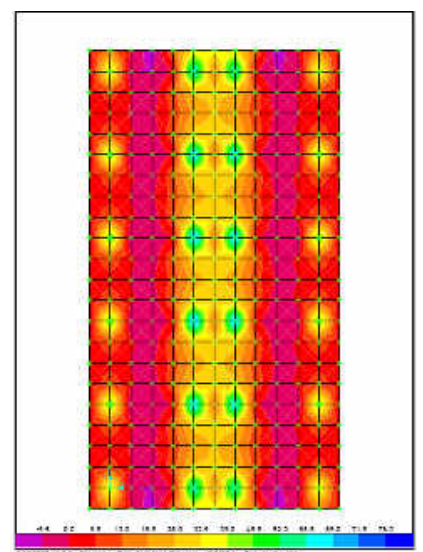

M11 (K2500t/m`)

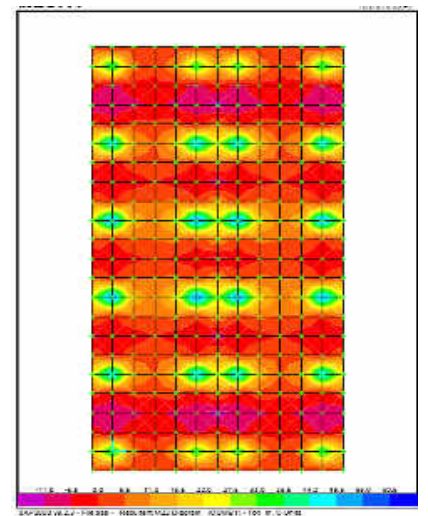

M22 (2500t/m')

(IV) Moment distribution on raft foundation with projection only Figure 3: Moment distribution on raft foundation 
The moment M11 and M22 will be determined in the critical section (in Xdirection at zero $\mathrm{m}, 4 \mathrm{~m}$, and $5 \mathrm{~m}$ and in Y-direction at zero $\mathrm{m}, 4 \mathrm{~m}, 8 \mathrm{~m}$, and $10 \mathrm{~m}$ ) on the raft foundation in case of use two side shear walls and a $1 \mathrm{~m}$ projection around the raft, the building without shear walls and without projection, and use two side shear walls and without projection.

Figures 4 (I) and (II) show the moment (M11) and moment (M22) curves respectively in the raft foundation with $\mathrm{K}=1500 \mathrm{t} / \mathrm{m}$ '. These curves show the relation between the moment and the distance at the critical section in the raft foundation in Xdirection for M22 and in Y-direction for M11.
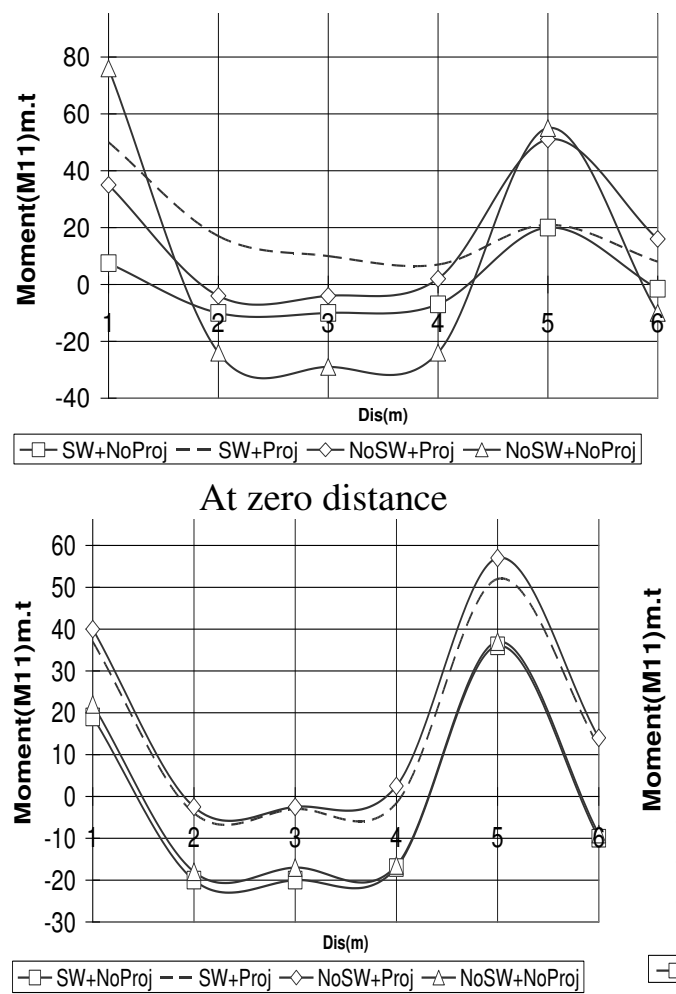

At $8 \mathrm{~m}$ in $\mathrm{Y}$-direction

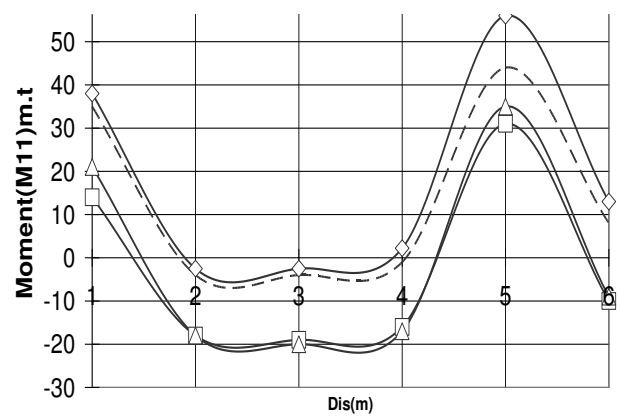

$-\square$ SW+NoProj -- SW+Proj $\prec$ NoSW+Proj $\neg-$ NoSW+NoPro

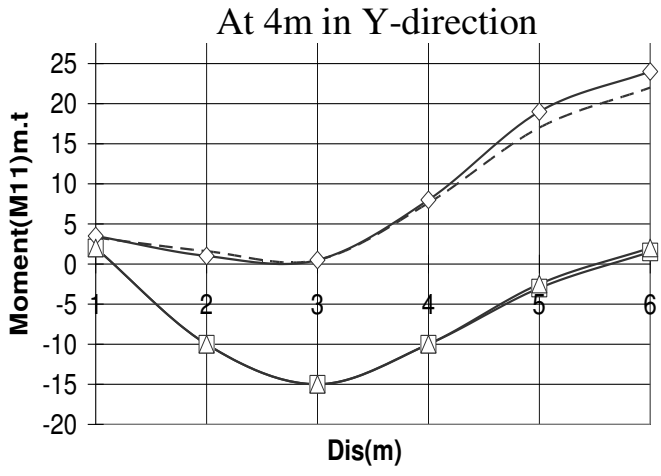

$-\square-\mathrm{SW}+$ NoProj $--\mathrm{SW}+$ Proj $\neg \diamond-$ NoSW+Proj $\neg-$ NoSW+NoProj

At $10 \mathrm{~m}$ in $\mathrm{Y}$-direction

\section{I) Moment M11}

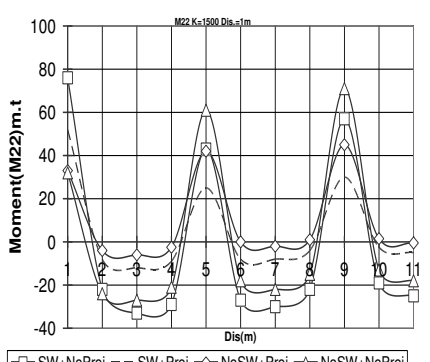

At zero distance

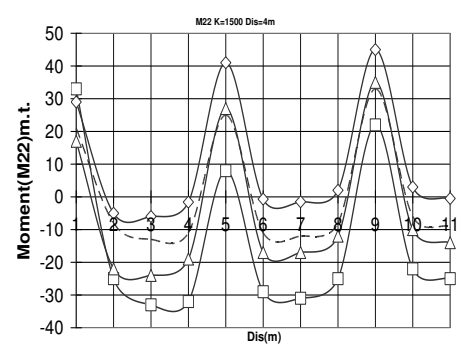

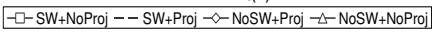

At $4 \mathrm{~m}$ in $\mathrm{X}$-direction

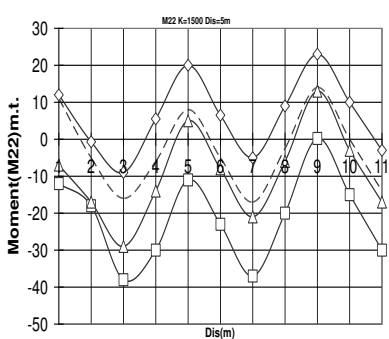

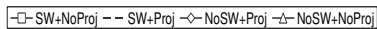

At $10 \mathrm{~m}$ in $\mathrm{X}$-direction

II) Moment M22

Figure 4: Moment of foundation under different condition of shear wall and projection With stiffness $\mathrm{K}=1500 \mathrm{t} / \mathrm{m}^{`}$ 
Figures 5 (I) and (II) show the moment (M11) and moment (M22) curves respectively in the raft foundation with $\mathrm{K}=2000 \mathrm{t} / \mathrm{m}^{\prime}$. These curves show the relation between the moment and the distance at the critical section in the raft foundation in $\mathrm{X}$ direction for M22 and in Y-direction for M11.

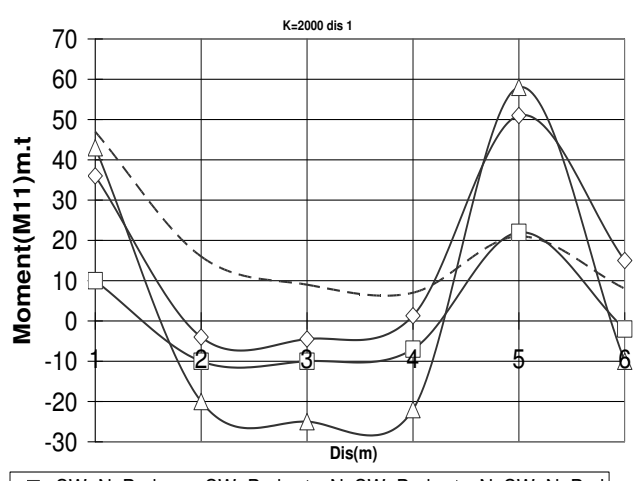

At zero distance

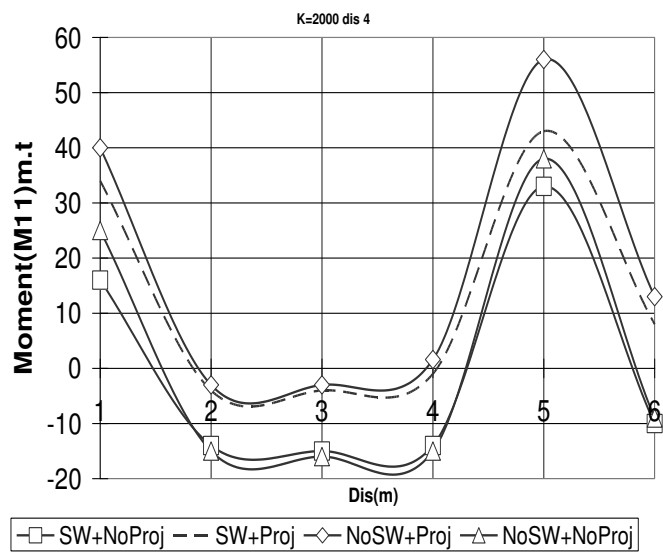

At $8 \mathrm{~m}$ in $\mathrm{Y}$-direction

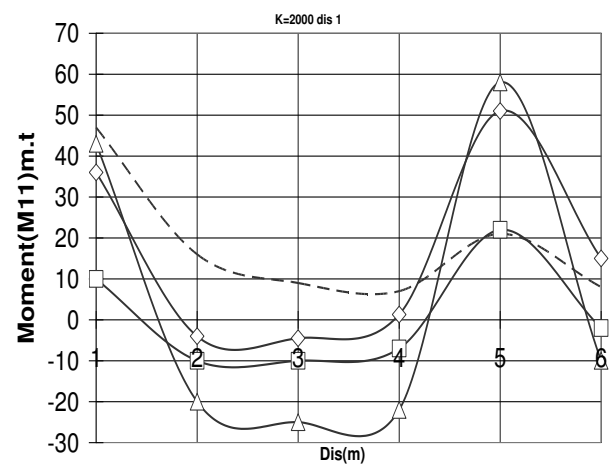

$-\square-\mathrm{SW}+$ NoProj $--\mathrm{SW}+$ Proj $\leadsto-\mathrm{NoSW}+$ Proj $\neg-$ NoSW+NoProj

At $4 \mathrm{~m}$ in $\mathrm{Y}$-direction

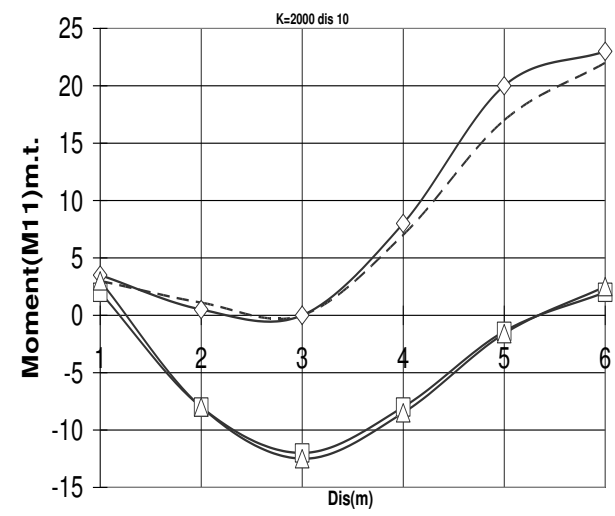

$-\square-$ SW+NoProj -- SW+Proj $\neg-$ NoSW+Proj $-\downarrow-$ NoSW+NoProj

At $10 \mathrm{~m}$ in $\mathrm{Y}$-direction

I) Moment M11

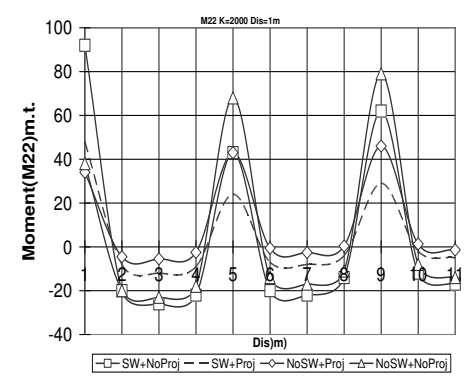

At zero distance

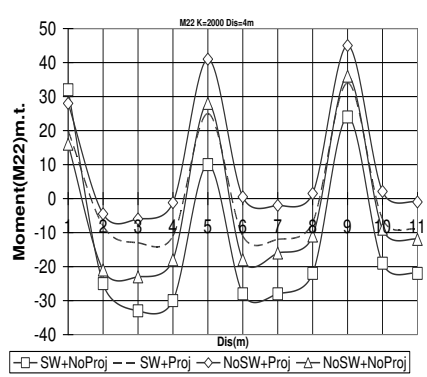

At $4 \mathrm{~m}$ in $\mathrm{X}$-direction

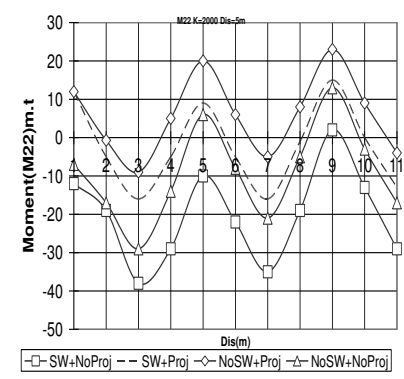

At $5 \mathrm{~m}$ in $\mathrm{X}$-direction

II) Moment M22

Figure 5: Moment of foundation under different condition of shear wall and projection With stiffness $\mathrm{K}=2000 \mathrm{t} / \mathrm{m}^{`}$ 
Figures 6 (I) and (II) show the moment (M11) and moment (M22) curves respectively in the raft foundation with $\mathrm{K}=2500 \mathrm{t} / \mathrm{m}$ '. These curves show the relation between the moment and the distance at the critical section in the raft foundation in $\mathrm{X}$ direction for M22 and in Y-direction for M11.

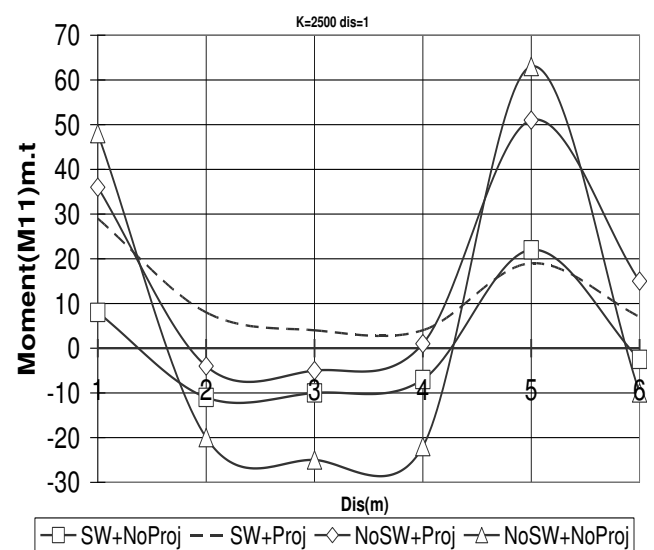

At Zero distance

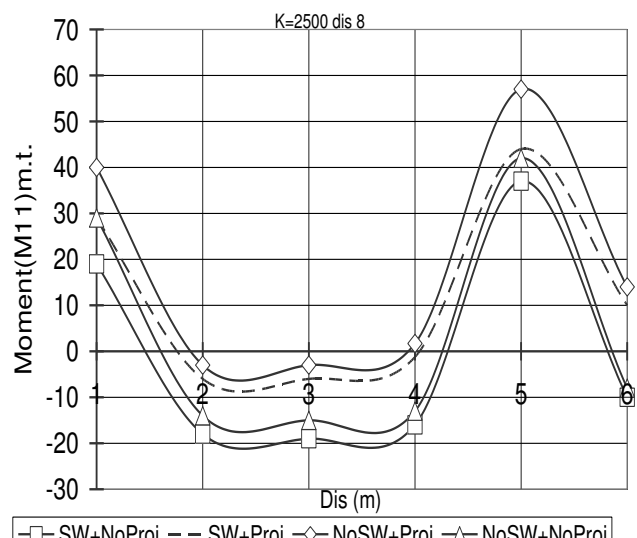

At $8 \mathrm{~m}$ in $\mathrm{Y}$-direction

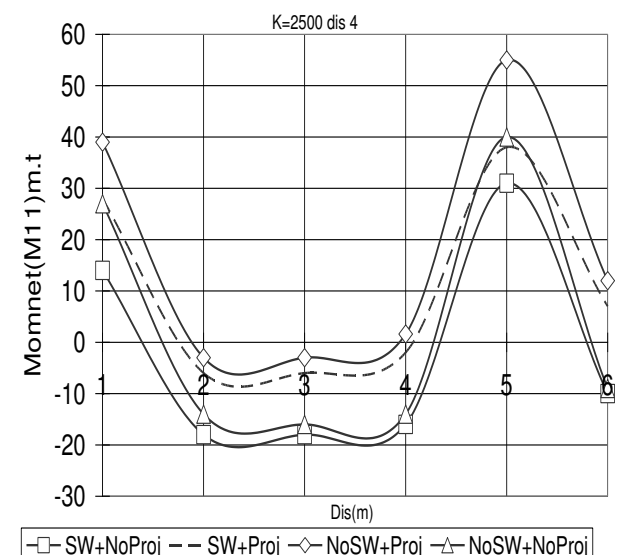

At $4 \mathrm{~m}$ in $\mathrm{Y}$-direction

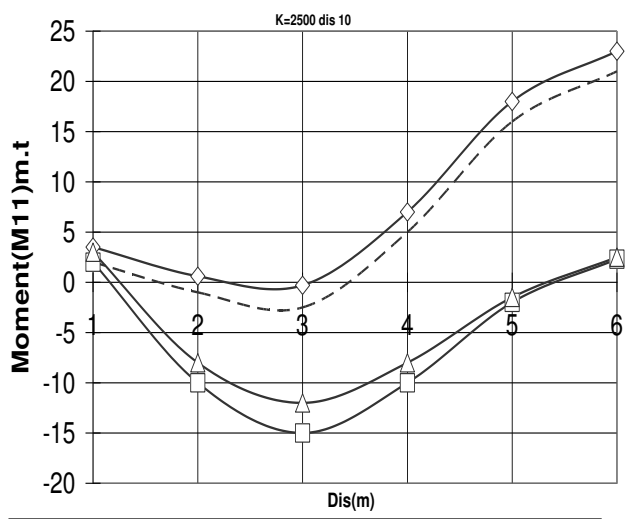

$-\square-$ SW+NoProj -- SW+Proj $\prec-$ NoSW+Proj $\neg-$ NoSW+NoProj

At $10 \mathrm{~m}$ in $\mathrm{Y}$-direction

I) Moment M11

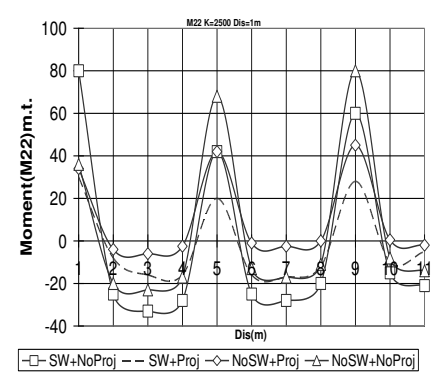

At Zero distance

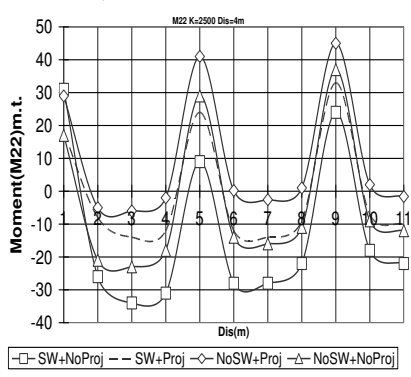

At $4 \mathrm{~m}$ in $\mathrm{X}$-direction

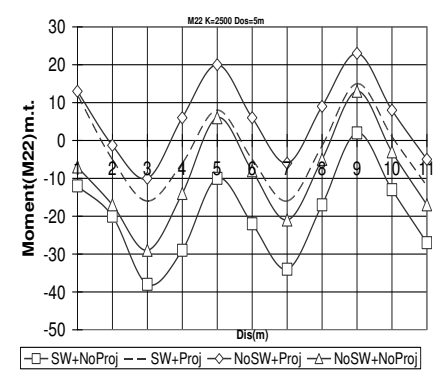

At $5 \mathrm{~m}$ in X-direction

\section{II) Moment M22}

Figure 6: Moment of foundation under different condition of shear wall and projection With stiffness $\mathrm{K}=2500 \mathrm{t} / \mathrm{m}^{`}$ 
Tables 1-I, 1-II, and 1-III show the ratio moment (M11) between the original case (no shear wall and no projection) and the other cases. From tables it can be recognized that:

- Table 1-I shows the ratio between SW+NoProj/ NoSW+NoProj, SW+Proj/ NoSW+NoProj, and NoSW+Proj/ NoSW+NoProj for distance 1m, 4m, 8m, and $10 \mathrm{~m}$ in Y-direction and $1 \mathrm{~m}, 2 \mathrm{~m}, 3 \mathrm{~m}, 4 \mathrm{~m}, 5 \mathrm{~m}$, and $6 \mathrm{~m}$ in X-direction with stiffness $K=1500 \mathrm{t} / \mathrm{m}$. For $1 \mathrm{~m}$ (place of shear wall) the ratio shows that the shear wall reduction M11 By nearly $60 \%$ and the case of only projection less than this by nearly $20 \%$. For $4 \mathrm{~m}$ the shear wall affect on M11 by decreasing it by nearly $30 \%$ but also the projection only case less than it by nearly $10 \%$. For $10 \mathrm{~m}$ the shear wall nearly identical with the projection only case that mean the effect of shear wall disappear in this distance but all decrease M11 by nearly $40 \%$.

- Table 1-II shows the ratio between SW+NoProj/ NoSW+NoProj, SW+Proj/ NoSW+NoProj, and NoSW+Proj/ NoSW+NoProj for distance 1m, 4m, 8m, and $10 \mathrm{~m}$ in Y-direction and $1 \mathrm{~m}, 2 \mathrm{~m}, 3 \mathrm{~m}, 4 \mathrm{~m}, 5 \mathrm{~m}$, and $6 \mathrm{~m}$ in X-direction with stiffness $K=2000 \mathrm{t} / \mathrm{m}^{\prime}$. For $1 \mathrm{~m}$ (place of shear wall) the ratio shows that the shear wall reduction M11 By nearly $50 \%$ and the case of only projection less than this by nearly $20 \%$. For $4 \mathrm{~m}$ the shear wall affect on M11 by decreasing its value by nearly $20 \%$ but also the projection only case less than it by nearly $10 \%$. For $10 \mathrm{~m}$ the shear wall case and projection nearly identical with the projection only case that mean the effect of shear wall disappear in this distance but all decreases M11 by nearly $40 \%$.

Table 1-III shows the ratio between SW+NoProj/ NoSW+NoProj, SW+Proj/ NoSW+NoProj, and NoSW+Proj/ NoSW+NoProj for distance $1 \mathrm{~m}$, am, 8m, and 10m in $\mathrm{Y}$-direction and $1 \mathrm{~m}, 2 \mathrm{~m}, 3 \mathrm{~m}, 4 \mathrm{~m}, 5 \mathrm{~m}$, and $6 \mathrm{~m}$ in $\mathrm{X}$-direction with stiffness $\mathrm{K}=2500 \mathrm{t} / \mathrm{m}$ '. For $1 \mathrm{~m}$ (place of shear wall), $4 \mathrm{~m}, 8 \mathrm{~m}$, and $10 \mathrm{~m}$ the cases of shear wall and projection and projection only are nearly identical and less than the case of no shear wall no projection by nearly $50 \%$.

Table 1: The ratio between the moment (M11) in No shear walls and No projection case and other cases in 1.0 distance, $4 \mathrm{~m}, 8 \mathrm{~m}$, and $10 \mathrm{~m}$ in $\mathrm{Y}$-direction

(I) $\mathrm{K}=1500 \mathrm{t} / \mathrm{m}^{\prime}$

\begin{tabular}{|c|c|c|c|c|c|c|c|c|c|c|c|c|c|}
\hline \multicolumn{2}{|c|}{$\operatorname{Dis}(m)$} & \multicolumn{3}{|c|}{1.0} & \multicolumn{3}{|c|}{4.0} & \multicolumn{3}{|c|}{8.0} & \multicolumn{3}{|c|}{10.0} \\
\hline \multirow{6}{*}{ 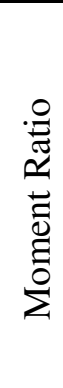 } & 1 & 0.1 & 0.7 & 0.5 & 0.7 & 1.7 & 1.8 & 0.9 & 1.7 & 1.8 & 1.0 & 1.7 & 1.8 \\
\hline & 2 & 0.4 & 0.7 & 0.2 & 1.0 & 0.2 & 0.1 & 1.1 & 0.2 & 0.1 & 1.0 & 0.2 & 0.1 \\
\hline & 3 & 0.3 & 0.3 & 0.1 & 1.0 & 0.2 & 0.1 & 1.2 & 0.2 & 0.1 & 1.0 & 0.0 & 0.0 \\
\hline & 4 & 0.3 & 0.3 & 0.1 & 0.9 & 0.1 & 0.1 & 1.0 & 0.1 & 0.2 & 1.0 & 0.8 & 0.8 \\
\hline & 5 & 0.4 & 0.4 & 0.9 & 0.9 & 1.3 & 1.6 & 1.0 & 1.4 & 1.5 & 1.2 & 6.8 & 7.6 \\
\hline & 6 & 0.2 & 0.8 & 1.6 & 1.1 & 0.9 & 1.4 & 1.1 & 1.3 & 1.6 & 0.8 & 11 & 12 \\
\hline
\end{tabular}


(II) $\mathrm{K}=\mathbf{2 0 0 0 t} / \mathbf{m}^{\prime}$

\begin{tabular}{|c|c|c|c|c|c|c|c|c|c|c|c|c|c|}
\hline \multicolumn{2}{|c|}{$\operatorname{Dis}(\mathrm{m})$} & \multicolumn{3}{|c|}{1.0} & \multicolumn{3}{|c|}{4.0} & \multicolumn{3}{|c|}{8.0} & \multicolumn{3}{|c|}{10.0} \\
\hline \multirow{6}{*}{ 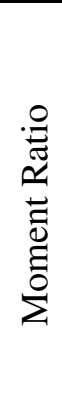 } & 1 & 0.2 & 1.1 & 0.8 & 0.6 & 1.4 & 1.6 & 0.9 & 1.4 & 1.5 & 0.7 & 1 & 1.2 \\
\hline & 2 & 0.5 & 0.8 & 0.2 & 0.9 & 0.3 & 0.2 & 1.1 & 0.2 & 0.2 & 1 & 0.1 & 0.1 \\
\hline & 3 & 0.4 & 0.4 & 0.2 & 0.9 & 0.3 & 0.2 & 0.9 & 0.2 & 0.2 & 1 & 0 & 0 \\
\hline & 4 & 0.3 & 0.3 & 0.1 & 0.9 & 0.1 & 0.1 & 1 & 0.1 & 0.1 & 0.9 & 0.8 & 0.9 \\
\hline & 5 & 0.4 & 0.4 & 0.9 & 0.9 & 1.1 & 1.5 & 1 & 1.2 & 1.4 & 0.9 & 11 & 13 \\
\hline & 6 & 0.2 & 0.8 & 1.5 & 1.1 & 0.9 & 1.4 & 1.4 & 1.7 & 2 & 0.8 & 8.8 & 9.2 \\
\hline
\end{tabular}

(III) $\mathrm{K}=2500 \mathrm{t} / \mathrm{m}^{`}$

\begin{tabular}{|c|c|c|c|c|c|c|c|c|c|c|c|c|c|}
\hline \multicolumn{2}{|c|}{ Dis(m) } & \multicolumn{3}{|c|}{1.0} & \multicolumn{3}{|c|}{4.0} & \multicolumn{3}{|c|}{8.0} & \multicolumn{3}{|c|}{10.0} \\
\hline \multirow{6}{*}{ 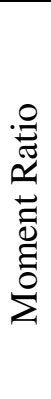 } & 1 & 0.2 & 0.6 & 0.8 & 0.5 & 1 & 1.4 & 0.7 & 1 & 1.4 & 0.7 & 0.7 & 1.2 \\
\hline & 2 & 0.6 & 0.4 & 0.2 & 1.3 & 0.4 & 0.2 & 1.3 & 0.4 & 0.2 & 1.3 & 0.1 & 0.1 \\
\hline & 3 & 0.4 & 0.2 & 0.2 & 1.1 & 0.4 & 0.2 & 1.3 & 0.4 & 0.2 & 1.3 & 0.2 & 0 \\
\hline & 4 & 0.3 & 0.2 & 0 & 1.1 & 0.1 & 0.1 & 1.2 & 0.1 & 0.1 & 1.3 & 0.6 & 0.8 \\
\hline & 5 & 0.3 & 0.3 & 0.8 & 0.8 & 1 & 1.4 & 0.9 & 1 & 1.4 & 1.3 & 11 & 12 \\
\hline & 6 & 0.3 & 0.7 & 1.5 & 1.1 & 0.8 & 1.3 & 1.3 & 1.3 & 1.8 & 0.9 & 8.4 & 9.2 \\
\hline
\end{tabular}

Tables 2-I, 2-II, and 2-III show the ratio moment (M22) between the original case (no shear wall and no projection) and the other cases. From tables it can be recognized that:

Table 2-I shows the ratio between SW+NoProj/ NoSW+NoProj, SW+Proj/ NoSW+NoProj, and NoSW+Proj/ NoSW+NoProj for distance $1 \mathrm{~m}$, to $11 \mathrm{~m}$ in Ydirection and $1 \mathrm{~m}, 4 \mathrm{~m}$, and $5 \mathrm{~m}$ in X-direction with stiffness $\mathrm{K}=1500 \mathrm{t} / \mathrm{m}$. For $1 \mathrm{~m}$ (place of shear wall) the ratio shows that the shear wall reduction M22 By nearly $60 \%$ and the case of only projection less than this by nearly $20 \%$. For $4 \mathrm{~m}$ the shear wall affect on M22 by decreasing its value by nearly $30 \%$ but also the projection only case less than it by nearly $30 \%$. For $10 \mathrm{~m}$ the shear wall and projection case nearly less than the projection case only by $40 \%$ but in general less than the original case by $30 \%$. By inspecting the two cases of stiffness $(K=2000$, and $K=2500)$ the results case be nearly as the case of stiffness $\mathrm{K}=1500 \mathrm{t} / \mathrm{m}$.

Table 2: The ratio between the moment (M22) in No shear walls and No projection case and other cases in 1.0 distance, $4 \mathrm{~m}$, and $5 \mathrm{~m}$ in X-direction 
(I) $K=1500 t / \mathrm{m}^{\prime}$

\begin{tabular}{|c|c|c|c|c|c|c|c|c|c|c|}
\hline \multicolumn{2}{|c|}{$\operatorname{Dis}(m)$} & \multicolumn{3}{|c|}{1.0} & \multicolumn{3}{|c|}{4.0} & \multicolumn{3}{|c|}{5.0} \\
\hline \multirow{10}{*}{ 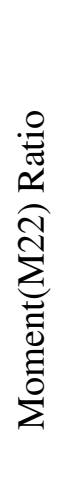 } & 1 & 2.4 & 1.6 & 1.0 & 1.9 & 1.2 & 1.7 & 1.7 & 1.6 & 1.7 \\
\hline & 2 & 0.9 & 0.3 & 0.2 & 1.1 & 0.4 & 0.2 & 1.1 & 0.3 & 0.0 \\
\hline & 3 & 1.2 & 0.4 & 0.2 & 1.4 & 0.5 & 0.3 & 1.3 & 0.6 & 0.3 \\
\hline & 4 & 1.4 & 0.4 & 0. & & .6 & J. & 2. & 0.4 & 0.4 \\
\hline & 5 & 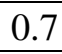 & 0.4 & 0 . & 0.3 & 0. & 1. & 2.2 & 1.6 & 4.0 \\
\hline & 6 & 1.5 & 0.4 & 0.0 & 1.7 & 0.6 & 0.0 & 2.9 & 0.6 & 0.8 \\
\hline & 7 & 1. & 0.4 & 0. & 1.8 & 0. & 0. & 1.8 & 0.8 & 0.2 \\
\hline & 8 & 1. & 0.3 & 0. & 2.1 & 0.7 & 0. & 3.3 & 0.4 & 1.5 \\
\hline & 9 & & 0.4 & 0. & 0.6 & 0. & 1. & 0.0 & 1.1 & 1.8 \\
\hline & 10 & 1.5 & 0.2 & 0.1 & 2.2 & 0.6 & 0.3 & 5.0 & 0.0 & 3.3 \\
\hline & 11 & 1.4 & 0.3 & 0.0 & 1.8 & 0.6 & 0.0 & 1.8 & 0.8 & 0.2 \\
\hline
\end{tabular}

(II) $\mathbf{K}=\mathbf{2 0 0 0 t} / \mathbf{m}$

\begin{tabular}{|c|c|c|c|c|c|c|c|c|c|c|}
\hline \multicolumn{2}{|c|}{$\operatorname{Dis}(\mathrm{m})$} & \multicolumn{3}{|c|}{1.0} & \multicolumn{3}{|c|}{4.0} & \multicolumn{3}{|c|}{5.0} \\
\hline \multirow{11}{*}{ 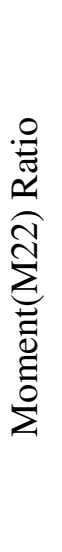 } & 1 & 2.4 & 1.3 & 0.9 & 2.0 & 1.3 & 1.8 & 1.7 & 1.7 & 1.7 \\
\hline & 2 & 1.0 & 0.4 & 0.2 & 1.2 & 0.4 & 0.2 & 1.1 & 0.3 & 0.0 \\
\hline & 3 & 1.1 & 0.5 & 0.2 & 1.4 & 0.6 & 0.3 & 1.3 & 0.6 & 0.3 \\
\hline & 4 & 1.2 & 0.5 & 0.1 & 1.7 & 0.6 & 0.1 & 2.1 & 0.4 & 0.4 \\
\hline & 5 & 0.6 & 0.4 & 0.6 & 0.4 & 0.9 & 1.5 & 1.7 & 1.5 & 3.3 \\
\hline & 6 & 1.4 & 0.5 & 0.0 & 1.6 & 0.6 & 0.0 & 2.8 & 0.6 & 0.8 \\
\hline & 7 & 1.3 & 0.5 & 0.2 & 1.8 & 0.8 & 0.1 & 1.7 & 0.8 & 0.2 \\
\hline & 8 & 1.3 & 0.4 & 0.0 & 2.0 & 0.6 & 0.1 & 3.8 & 0.2 & 1.6 \\
\hline & 9 & 0.8 & 0.4 & 0.6 & 0.7 & 0.9 & 1.3 & 0.2 & 1.2 & 1.8 \\
\hline & 10 & 1.5 & 0.3 & 0.2 & 2.1 & 0.7 & 0.2 & 4.3 & 0.0 & 3.0 \\
\hline & 11 & 1.2 & 0.4 & 0.1 & 1.8 & 0.8 & 0.1 & 1.7 & 0.8 & 0.2 \\
\hline
\end{tabular}

(III)K=2500t/m

\begin{tabular}{|c|c|c|c|c|c|c|c|c|c|c|}
\hline \multicolumn{2}{|c|}{$\operatorname{Dis}(\mathrm{m})$} & \multicolumn{3}{|c|}{1} & \multicolumn{3}{|c|}{4} & \multicolumn{3}{|c|}{5} \\
\hline \multirow{11}{*}{ 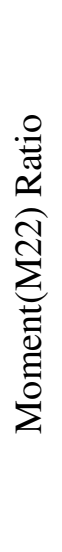 } & 1 & 2.2 & 0.8 & 0.9 & 1.8 & 1.1 & 1.7 & 1.7 & 1.7 & 1.9 \\
\hline & 2 & 1.3 & 0.4 & 0.2 & 1.2 & 0.4 & 0.2 & 1.2 & 0.3 & 0.1 \\
\hline & 3 & 1.4 & 0.7 & 0.3 & 1.5 & 0.6 & 0.3 & 1.3 & 0.6 & 0.3 \\
\hline & 4 & 1.6 & 0.9 & 0.1 & 1.7 & 0.7 & 0.1 & 2.1 & 0.4 & 0.4 \\
\hline & 5 & 0.6 & 0.3 & 0.6 & 0.3 & 0.8 & 1.4 & 1.7 & 1.3 & 3.3 \\
\hline & 6 & 1.9 & 1.2 & 0.1 & 2.0 & 0.9 & 0.0 & 2.8 & 0.6 & 0.8 \\
\hline & 7 & 1.6 & 1.0 & 0.1 & 1.8 & 0.9 & 0.2 & 1.6 & 0.8 & 0.3 \\
\hline & 8 & 1.8 & 1.1 & 0.0 & 2.0 & 0.8 & 0.1 & 3.4 & 0.3 & 1.8 \\
\hline & 9 & 0.8 & 0.4 & 0.6 & 0.6 & 0.9 & 1.2 & 0.2 & 1.2 & 1.8 \\
\hline & 10 & 1.9 & 1.3 & 0.1 & 2.0 & 0.8 & 0.2 & 4.3 & 0.3 & 2.7 \\
\hline & 11 & 1.5 & 0.4 & 0.1 & 1.8 & 0.8 & 0.1 & 1.6 & 0.7 & 0.3 \\
\hline
\end{tabular}




\section{CONCLUSIONS}

The dynamic analysis concludes that the slender high rise buildings are significantly affected by earthquake characteristic. The cases studied showed that the slender high rise building with shear walls and raft foundation projections is the most reliable system in resisting the accidental forces, especially when the raft foundation rests on weak soil. The following important conclusions can be drawn out from the foregoing presentation:

- Effectiveness of the shear walls is achieved by decreasing substantially the base shears induced in the columns. The base shear reduces by $50 \%$ compared with the slender high rise building without shear walls.

- The results demonstrated efficiently the role of shear walls in the analysis of such kind of buildings. Existence of shear walls result in considerable decrease of the bending moments in both directions in the raft and distributing the seismic forces on the columns depending on the subgrad modulus.

- Execution of raft foundation projection reduces the internal forces in the raft, but on the other side the projection produces enormous base shear in the corner columns and this deserves more attention and should be included in the design of these columns.

- The shear walls and projections of raft proved to be highly advantageous of use in the slender high rise buildings resting on a weak soil.

\section{REFERENCES}

[1] Ali, M. M., (2001), "Evolution of Concrete Skyscrapers: from Ingalls to Jinmao", Electronic Journal of Structural Engineering

[2] "The Egyptian Code for Calculation of loads and Forces in Structural Building Work, ECOL 201" housing and Building Research Center, Cairo, Egypt, September 2008.

[3] Elnashai, A. and KUCHMA A. D. Report 07-14 September 2007 Mid-America Earthquake Center-Headquarter: University of Illinois at Urbana-Champaign

[4] Hjelmstad, K. D., (2005), "Fundamentals of structural mechanics", 2nd edition, ISBN 038723330X, Springer

[5] Khan, F. R. and Rankine, J., (1980), "Structural Systems", Tall Building Systems and Concepts Council on Tall Buildings and Urban Habitat/American Society of Civil Engineers, Vol. SC, pp. 42

[6] "SAP200, Nonlinear version11, Static and Dynamic Finite Elements Analysis of Structure" Computers\& Structures, Inc., Berkeley, U.S.A., 2007. 


\section{دور حوائط القص في المباني النحيفة ذات الارتفاعات العالية}

اصبحت المبانى النحيفة ذات الارتفاعات العالية شائعة التتفيذ فى مصر و كثثر منها يتعرض للميول نتيجة عدم وجود احتياطات صريحة من المهندس المصمم وتقدير محتمل لمواجهة الخطر الناجم عن تعرض هذه المنشات للزلازل. قد اعدت هذه الدراسة لتتاقش و تعلل دور بعض ونس العوامل الهامـة

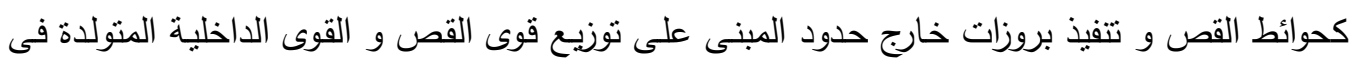

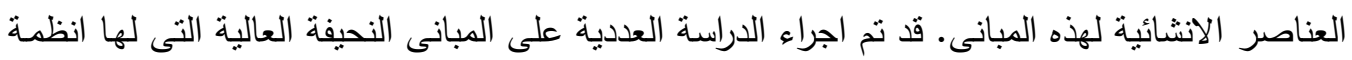

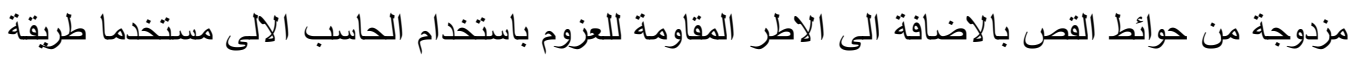

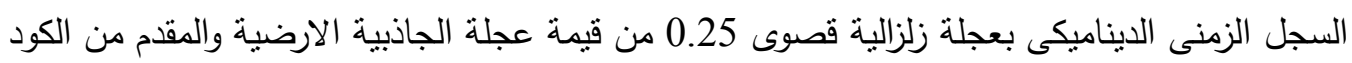

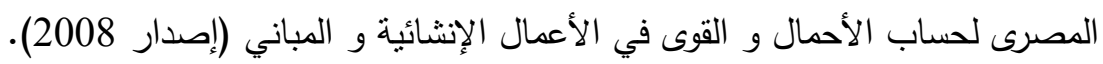

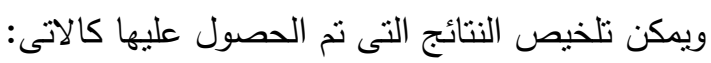

1- حوائط القص لها دور فعال و جوهرى فى اعادة توزيع و تقليل قوى القص على الاعمدة و اثبت

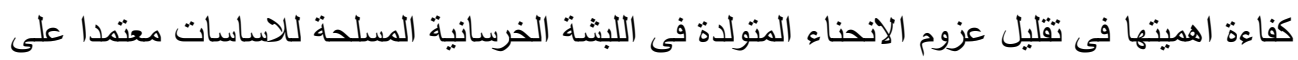
نوع التربة المرتكزة عليها.

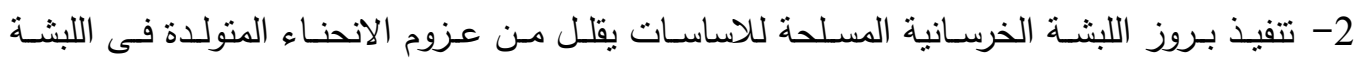

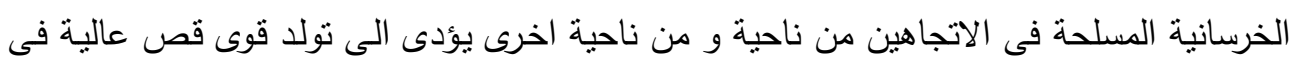
اعمدة الاركان يجب ان يؤخذ فى الاعتبار عن تصميم هذه الاعمدة.

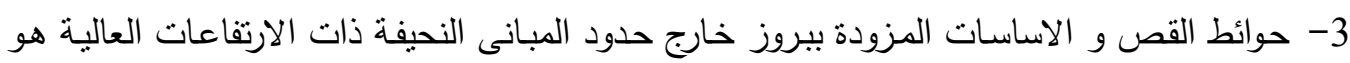
افضل الأنظمة لمقاومة قوى القص و القوى الداخلية الناجمة عن احمال الزلازل. 